\title{
The Observations of Student Teachers in Regard to Professional Qualifications of Advisor Teachers During Teaching Practicum
}

\author{
Savaş KARAGÖZ1, M. Emir RÜZGAR²
}

\section{ARTICLE INFO}

\section{Article History:}

Received 01.12.2019

Received in revised form

19.02.2020

Accepted

Available online 01.03.2020

\begin{abstract}
This study was conducted to determine the inadequate professional qualifications of advisor teachers. Employing a qualitative approach, we studied the question "what are your observations regarding the professional qualifications of the advisor teachers during the teaching practicum?" with senior students in various programs such as Turkish, English, mathematics, painting, music and primary school teaching at the Faculty of Education of a small-scale state university in central Turkey. Analyzing the observations of the prospective teachers, we identified seven aspects of inadequate qualifications: (1) professionalism, (2) classroom management, (3) communication, (4) professional development, (5) personality, (6) creating a democratic classroom environment, and (7) usage of instructional material and technology. In terms of professionalism, the analysis yielded that some of the inadequate qualifications are favoring some students over to others and not having the ability to solve problems. With regard to classroom management, the most frequent inadequate qualifications are not taking individual differences into consideration and not being able to ensure student participation to lectures. Regarding communication, lack of communication among educational shareholders and negatively criticizing students are mostly mentioned by student teachers. Based on the findings of the study, we suggest that educational authorities provide in-service training sessions to teachers to work on these problems so that the quality of instruction would increase in schools.
\end{abstract}

(C) IJERE. All rights reserved

Keywords:

Teaching practicum, teacher candidates, professional qualifications of teachers.

\section{INTRODUCTION}

Teaching practicum is a process in which a student teacher carries activities as well as in-class teaching practices in an actual school in order to gain teaching skills and experiences (Trumbull and Fluet, 2008). In the history of Turkish Education, the process of cerre çıma in madrasas, Practicum within boys' teacher school that was established in 1848, the activities of senior students to gain experiences in the field at the institutions that educated teachers starting from Village Teacher School and Village Institutes to today are examples of teaching practicum (Abazaoğlu, Yıldırım ve Yıldızhan, 2016).

In the present age, the qualifications that individuals are supposed to have diversify. It is without a doubt that education is seen as the sole facilitator to equip individuals with these qualifications. In this process, teachers carry various responsibilities to equip themselves, their students, and in the long run, the society with new skills and values. In the modern societies, teachers are not just technicians that deal with education and instruction; rather, they are role models to students and the society. Such societal expectations from teachers necessitate defining a qualified teacher with all necessary qualifications and applying policies for teacher education to educate such a teacher (MEB, 2017).

A teacher is a main figure in the scene of education, and it is expected from them to make up for shortcomings in the sources and mistakes in the curricula. It is for this reason that it can be said that the success of education depends upon the quality of instruction in classrooms. In terms of teaching vocation,

1 Corresponding author: Aksaray University, Faculty of Education, Department of Educational Sciences. Aksaray, TURKEY. Email: savaskaragoz@aksaray.edu.tr. ORCID: 0000-0002-4410-9214

2 Aksaray University, Faculty of Education, Department of Educational Sciences. Aksaray, TURKEY. Email: memirruzgar@aksaray.edu.tr. ORCID: 0000-0001-6372-1233 
this statement means that instruction and learning are dependent upon teacher qualification (Çelebi, Babaoğlan, Selçuk and Peker, 2018). Teachers are generally evaluated by "inspector evaluation, in-class and out of class evaluation, student evaluation, student achievement for teacher evaluation, parent views, evaluating vocational studies of teachers, performance assessment, systematic observation of teacher, executive reports, teacher tests, peer evaluation." (Pehlivan, Demirbaş and Eroğlu, 2001; Çelebi, Babaoğlan, Selçuk and Peker, 2018).

Self-renewal and self-improvement are necessities for an information society in the 21st century and they are hence vital teacher qualifications. Ministry of National Education of Turkey has organized Teaching Vocation General Qualifications into three general qualification areas (Professional knowledge, professional skill, and attitude and values) and 11 sub areas that are related to and complement each other (MEB, 2017). Table 1 presents these qualifications.

Table 1

Ministry of National Education general qualifications of teaching profession

\begin{tabular}{ll}
\hline A. Professional Knowledge & $\begin{array}{l}\text { A teacher has advanced theoretical, methodological and } \\
\text { conceptual knowledge that encompass an interrogative view } \\
\text { in his or her subject. }\end{array}$ \\
\hline A1. Subject knowledge & $\begin{array}{l}\text { A teacher has mastery over curricula and pedagogical subject } \\
\text { knowledge in his or her subject. }\end{array}$ \\
\hline A3. Knowledge of regulations & $\begin{array}{l}\text { A teacher acts accordingly to regulations in regard to his or } \\
\text { her duty, right and responsibilities as a person and as a } \\
\text { teacher. }\end{array}$ \\
\hline B. Professional Skills & $\begin{array}{l}\text { A teacher effectively plans education and instruction } \\
\text { processes. }\end{array}$ \\
\hline $\begin{array}{l}\text { B1. Planning of education and } \\
\text { instruction }\end{array}$ & $\begin{array}{l}\text { A teacher prepares healthy and safe learning environments } \\
\text { for all of the students where effective learning could take } \\
\text { place. }\end{array}$ \\
\hline B2. Creating learning environment & A teacher effectively executes teaching and learning process. \\
\hline $\begin{array}{l}\text { B3. Management of teaching and } \\
\text { learning processes }\end{array}$ & $\begin{array}{l}\text { A teacher utilizes measurement and evaluation, method, } \\
\text { technique and tools purposefully. }\end{array}$ \\
\hline B4. Measurement and evaluation & A teacher pays regard to national, spiritual and global values. \\
\hline C. Attitude and Values & $\begin{array}{l}\text { A teacher has an attitude that would be supportive to } \\
\text { students' improvement. }\end{array}$ \\
\hline $\begin{array}{l}\text { C1. National, spiritual and global } \\
\text { values }\end{array}$ & $\begin{array}{l}\text { A teacher has effective communication and cooperation with } \\
\text { students, peers, parents and other educational shareholders. }\end{array}$ \\
\hline C2. Approach to students & $\begin{array}{l}\text { A teacher utilizes self-evaluation and attends studies for } \\
\text { personal and professional development. }\end{array}$ \\
\hline $\begin{array}{l}\text { C3. Communication and } \\
\text { cooperation }\end{array}$ & \\
\hline $\begin{array}{l}\text { C4. Personal and Professional } \\
\text { development }\end{array}$ & \\
\hline
\end{tabular}

In order to equip student teachers with the qualifications in the Table 1, the Directive for the process of student teachers' practicum at schools of Ministry of National Education was prepared in accordance to National Education Fundamental Law, no. 1739, dated 14.06.1973, to Statutory Decree on Organization and Duties of Ministry of National Education, no. 652, dated 25.08.2011, to Higher Education Law, no. 2547, dated 04.11.1981 and to Decree Regarding Ministry of National Education's Administrators and Teachers Teaching Hours and Extra Hours, dated 01.12.2006. The Directive regulates the process for better preparing students teachers for the profession of teaching as well as for creating a chance for them to put into use the 
general knowledge, specific area knowledge, knowledge, skill, attitude and behavior that they acquired during their education in a real life instructional environment (MEB, 2018).

The Directive lists the following principles for teaching practicum:

1. Planning of teaching practicum,

2. Cooperation and coordination between institutions,

3. Practice in an institutional environment,

4. Expanding the practicum in long period of time,

5. Cooperative evaluation,

6. Scope and variety,

7. Doing the practicum in the field and controlled,

8. The continuity of practicum and personnel development

In addition to the qualifications that teachers need to acquire, teachers need to have many other qualities such as being open-minded and objective toward students, taking students' expectations and needs into consideration, researching educational problems with scientific methods, taking individual differences into consideration, being open to innovations and developments, being able to understand and interpret societal developments and being able to follow technological developments (Çelikten, Sanal and Yeni, 2005; Özer and Gelen, 2008). The aforementioned qualifications are of great importance since the realization of objectives of educational and instructional institutions is first and foremost dependent upon the quality of teachers. In other words, the qualifications of teachers that they acquire and perform is an indicator of quality of instruction.

The acceptance that student teachers are colleagues of teachers in classrooms accentuate the fact there is information that teachers could learn from student teachers. In this sense, there is a lot of things that teachers could learn in regard to culture of teaching. Such an exchange between teachers and student teachers provides teachers an opportunity to increase their self-awareness and to evaluate their teaching practices (Sabuncuoğlu, 2016). Buldu (2014) identified the systems in Turkey that determine and measure performance and qualification level of teachers from their employment till retirement. He (2014) argued that there exists a mismatch between teachers' qualifications and performance. He (2014) also added that evaluations for teachers' qualification level is being done either by school principals or inspectors by using short-term classroom observations once a year. It is necessary to employ different evaluation types for teacher qualifications since the literature attest that majority of such evaluations are short-term. One such evaluation type could be the views of student teachers toward their teachers at schools during their practicum at actual schools with regard to teachers' qualifications.

\section{The Purpose of the Study}

The primary purpose of the study is to determine inadequate qualifications that teachers have as student teachers who are senior students at a program in a small sized state University at central Turkey observe them during their practicum in the 2019-2020 academic year. In order to achieve this purpose, the data were gathered in order to answer the question "What are the professional qualifications that your advisor teachers lack in your opinion that you observe during your practicum" from senior students at the Faculty of Education.

\section{Significance of the Study}

The present study has been conducted by paying attention to the principles of the practicum process and continuity of personnel development. In the milieu of teaching practicum, there is a need for evaluating advisor teachers as well as student teachers since only evaluating student teachers do not give a full picture of teaching practicum. The evaluation of advisor teachers, in this picture, is quite significant since the quality of teaching practicum influences the teacher quality. Said another way, it is necessary that there exists a reciprocal learning process between advisor teachers and student teachers, i.e., just as student teachers learn from their advisor, advisors should learn from student teachers. Besides, the literature on teaching practicum processes attest that in previous studies, either the advisor teacher evaluates the student teacher or student 
teachers evaluate existing teaching practices. The present study has a potential to contribute to the discussions on teaching practicum since it provides a new breath to the literature where students teachers have a chance to identify the lacking professional qualifications that their advisor teacher has. Moreover, the study gives a chance to student teachers to observe their advisors and reflect on what type of a teacher they want to be as in a form of self-assessment.

\section{METHOD}

\section{The Participants}

A total of 224 teacher candidates participated in the study where they were asked to identify the lacking professional qualifications of the advisor teachers that they work with. Participants were senior students at the Faculty of Education of a state university in central Turkey during 2019-2020 academic year specializing in mathematics, primary school teaching, Turkish, English, music and painting. Convenience sampling was utilized to recruit the participants. As a result of this sampling technique, researchers collected data from senior students at the Faculty of Education of a state university in central Turkey to identify deficient professional qualifications of advisor teachers from the perspective of teacher candidates. Table 2 presents the distribution of participants in regard to their specialization.

Table 2 Specialization areas of participants

\begin{tabular}{lll}
\hline Specialization & Number & \% \\
\hline Mathematics & 54 & $\mathbf{2 4 . 1 1}$ \\
Primary school teaching & 51 & $\mathbf{2 2 . 7 7}$ \\
Turkish & 37 & $\mathbf{1 6 . 5 2}$ \\
English & 32 & $\mathbf{1 4 . 2 9}$ \\
Music & 31 & $\mathbf{1 3 . 8 4}$ \\
Painting & 19 & $\mathbf{8 . 4 7}$ \\
\hline TOTAL & 224 & $\mathbf{1 0 0}$ \\
\hline
\end{tabular}

As can be seen from Table 2, of the 224 participants, 54 of them $(24.11 \%)$ specialize in mathematics, 51 of them $(22.77 \%)$ in primary school teaching, 37 of them in Turkish (16.52\%), 32 of them (14.29\%) in English, 31 of them $(13.84 \%)$ in music and 19 of them $(8.47 \%)$ in painting.

\section{Data Collection}

Peer observation is a professional development activity in which teachers observe each other reciprocally. This professional development activity is an incentive both for the observed and the observer. In this sense, it can be a powerful tool for not only professional development but also increasing the quality of in-class instruction. In other words, peer observation model gives teachers an opportunity to be aware of different teaching styles as well as various options and possibilities for teaching and to reflect these new knowledge and skill to classrooms (Sabuncuoğlu,2016).

During data collection, researchers proposed the question "What are the professional qualifications that your advisor teacher lack in your opinion that you observe during your practicum." Participants answered this question during an open discussion session. The researchers recorded participants' responses and by thus creating the dataset for the study.

\section{Data Analysis}

The method of content analysis was utilized in order to analyze the data. The main aim of content analysis is to create codes from data pieces that have similar attributes (Selçuk, Palancl, Kandemir and Dündar, 2014). In that regard, researchers read the data to identify similarities in the data and then created codes based on these similarities. Researchers included frequencies of the created codes by taking the occurrence of codes in the dataset.

\section{FINDINGS}


The main aim of this study was to determine inadequate qualifications that teachers have as student teachers who are senior students at a program in a small sized state University at central Turkey observe them during their practicum in the 2019-2020 academic year. In this section, the findings that were created as a result of data analysis are presented. Data analysis yielded seven themes that can be seen in Table 3.

Table 3 Inadequate advisor teacher qualifications

\begin{tabular}{lll}
\hline Themes & f & Percentage \\
\hline Professionalism & 54 & 24.08 \\
Classroom management & 50 & 22.32 \\
Communication & 40 & 17.80 \\
Professional development & 34 & 15.10 \\
Personality & 29 & 13.10 \\
Creating a democratic classroom environment & 9 & 4 \\
Usage of instructional material and technology & 8 & 3.6 \\
\hline TOPLAM & $\mathbf{2 2 4}$ & $\mathbf{1 0 0}$ \\
\hline
\end{tabular}

As Table 3 shows, seven inadequate professional qualifications of advisor teachers in the opinion of the participants are professionalism $(24,08 \%)$, classroom management $(22,32 \%)$, communication $(17,80 \%)$, professional development $(15,10 \%)$, personality $(13,10 \%)$, creating a democratic classroom environment $(4 \%)$ and usage of instructional material and technology (3.6), respectively.

Table 4 Codes for professionalism theme

\begin{tabular}{ll}
\hline Code & f \\
\hline Having favorite students - favoring some students over to others & 6 \\
Not having the ability to solve problems & 5 \\
Not having the ability to teach effectively & 4 \\
Reflecting personal problems to work & 4 \\
Apathy to refugee students & 4 \\
Labeling students - having predefined thoughts about students & 4 \\
Utilizing punishment & 4 \\
Yelling-intimidation & 3 \\
Humiliating students and hurting their self-confidence & 3 \\
Teachers' conversation of inappropriate content & 3 \\
Factionalism between teachers & 3 \\
Politics among teachers & 3 \\
Not keeping a professional distance from students & 3 \\
Unrealistic optimism & 2 \\
Being unprepared to class & 2 \\
Leaving the class in the middle of session & 2 \\
\hline TOTAL & 54 \\
\hline
\end{tabular}

As can be seen from Table 4, according to student teachers, the inadequate qualifications of advisor teachers during practicum in relation to professionalism are favoring some students over to others, not having the ability to solve problems, not having the ability to teach effectively, reflecting personal problems to work, apathy to refugee students, labeling students, utilizing punishment, intimidation, humiliating students and hurting their self-confidence, teachers' conversation of inappropriate content, factionalism between teachers, politics among teachers, not keeping a professional distance from students, unrealistic optimism, being unprepared to class and leaving the class in the middle of session. These issues attest that advisor teachers lack some fundamental qualifications as they perform their duty and thus set a negative image to student teachers. 
Table 5 Codes for classroom management theme

\begin{tabular}{ll}
\hline Code & f \\
\hline Not taking individual differences into consideration & 20 \\
Not being able to ensure student participation to & 12 \\
lectures & \\
Not using classroom time effectively and efficiently & 10 \\
Not reaching to whole class during instruction & 8 \\
\hline TOTAL & $\mathbf{5 0}$ \\
\hline
\end{tabular}

Table 5 indicates that in terms of classroom management, advisor teachers do not take individual differences of students into consideration in their teaching. Similarly, they also do not create an inclusive learning environment where all of the students would participate to session, i.e., only some of the students participate in the class effectively where the other students just listen passively. Also, advisor teachers are of the opinion that advisor teachers do not manage the class time efficiently. Finally, advisor teachers do not reach to all of the students according to student teachers.

Table 6 Codes for communication theme

\begin{tabular}{ll}
\hline Code & f \\
\hline Lack of communication among educational shareholders & 12 \\
Negatively criticizing students & 8 \\
Negative attitude toward students & 6 \\
Poor utilization of language & 5 \\
Failing to establish a healthy relationship with families & 5 \\
Monotonous voice & 4 \\
\hline TOTAL & 40 \\
\hline
\end{tabular}

Table 6 indicates that advisor teachers fail to establish a healthy communication system among their peers and coworkers such as colleagues, administrators, inspectors, etc. The absence of this communication among significant members of the educational system might result in a decrease in the quality of instruction that is provided to students. Student teachers, on the other hand, claim that teachers criticize students in a negative way, which is detrimental to psychological well-being of students. Not only that, advisor teachers sometimes have a negative attitude toward their students. Similarly, teacher candidates assert that advisor teachers use the language poorly when they deliver instruction to students or converse in general. Additionally, although a healthy relationship between teachers and students' families is vital for students' achievement in schools, student teachers enounce that their advisor teachers fail to do that. Finally, advisor teachers sometime utilize a monotonous voice, which may bore students and hence decrease their motivation toward the instruction. 
Table 7 Codes for professional development theme

\begin{tabular}{lc}
\hline Code & f \\
\hline Time management & 4 \\
Not having enough knowledge in terms methods and techniques of instruction & 4 \\
Not using enough material & 3 \\
Burnout - disliking the profession of teaching & 3 \\
Failure to consider students' readiness level in instruction & 3 \\
Ignoring students with special needs & 3 \\
Failure to keep up with recent developments in the field & 3 \\
Not being able read curricula & 2 \\
Teacher-centered instruction & 2 \\
Focusing only on academic achievement & 2 \\
Not providing feedback & 1 \\
Planlessness & 1 \\
Not using Turkish effectively & 1 \\
Not using body language effectively & 1 \\
Being too passive. & 1 \\
\hline TOTAL & 34 \\
\hline
\end{tabular}

In terms of professional development, as summarized in Table 7, students teachers argue that advisor teachers are mainly inadequate in quite a few qualifications such as time management, not having enough knowledge in terms methods and techniques of instruction, not using enough material, disliking the profession of teaching, failure to consider students' readiness level in instruction, ignoring students with special needs and failure to keeping up with recent developments in the field, not being able read curricula, teacher-centered instruction, focusing only on academic achievement rather than promoting students' holistic development, not providing feedback, planlessness, not using Turkish effectively, not using body language effectively and being too passive.

Table 8 Codes for personality theme

\begin{tabular}{ll}
\hline Code & f \\
\hline Psychological violence against students & 4 \\
Humiliating students & 4 \\
Being a negative role model & 3 \\
Not being focused & 3 \\
Being dictatory & 3 \\
Lacking the ability to empathize & 3 \\
Anger management & 3 \\
Being too authoritarian & 2 \\
Being grumpy & 1 \\
Being egoist & 1 \\
Intolerantness & 1 \\
Not having the ability for preventive guidance & 1 \\
\hline TOTAL & $\mathbf{2 9}$ \\
\hline
\end{tabular}

Table 8 lists 12 codes for personality theme from the data analysis. These codes attest that from the perspective of student teachers, advisor teachers perform psychological violence against students while also in some instance humiliating them. In addition, in the mind of teacher candidates, advisor teachers set a negative role model to students because of their inadequacy in these professional qualifications. Moreover, 
student teachers also stated that advisor teachers carry some other inadequate professional qualifications in the aspect of personality such as not being focused, being dictatory, lacking the ability to empathize, anger management, being too authoritarian, being grumpy, being egoist, intolerantness, not having the ability for preventive guidance.

Table 9 Coder for creating a democratic classroom environment theme

\begin{tabular}{ll}
\hline Code & f \\
\hline Not giving students chances to express themselves & 7 \\
Insulting students & 2 \\
\hline TOTAL & $\mathbf{9}$ \\
\hline
\end{tabular}

As listed on Table 9, two codes were identified within theme of creating a democratic classroom environment. Student teachers contend that advisor teachers do not allow students to express themselves freely, which is detrimental to a democratic environment in classroom. What is more, unfortunately, student teachers argued that they witnessed instances where their advisor teacher insulted students.

Table 10 Codes for usage of instructional material and technology

\begin{tabular}{lc}
\hline Code & $\mathbf{f}$ \\
\hline Not being able to utilize technology (smartboards particularly) & 4 \\
Inadequacy to utilize a wide variety of materials & 3 \\
Using the board inefficiently & 1 \\
\hline TOTAL & $\mathbf{8}$ \\
\hline
\end{tabular}

As indicated in Table 10, the three codes within usage of instructional material and technology attest that student teachers believe that their advisor teachers fail to utilize a wide variety of instructional materials to promote student achievement. Similarly, advisor teachers are not able to make the most of different technologies in their classrooms, especially smartboards.

\section{CONCLUSION}

Professional qualifications are crucial for educational quality in the $21^{\text {th }}$ century. For this reason, educational authorities keep developing and updating these qualifications. In this study, we aimed to identify inadequate professional qualities that advisor teachers have from the perspective of student teachers. We identified seven general categories: Professionalism, Classroom Management, Communication, Professional Development, Personality, Creating a Democratic Classroom Environment and Usage of Instructional Material and Technology, respectively. In terms of professionalism, it is alarming that student teachers claim that advisor teachers suffer from such professionalism issues as favoring some students over to others, not having the ability to solve problems, not having the ability to teach effectively, reflecting personal problems to work. Since teacher quality is the single most important variable that affects individual student achievement (Darling-Hammond, 2000) as well as the achievement at the country level (Akiba, LeTendre \& Scribner, 2007), it is of utmost importance that teachers attain an encompassing level of professionalism to eliminate their shortcomings, thus, increasing the quality of instruction that they deliver to students. In the matter of classroom management, the findings yield that advisor teachers do not take individual differences into consideration, are not able to ensure student participation to lectures, do not use classroom time efficiently and do not reach to whole class during instruction. Classroom management is one of the basic 
qualifications that every teacher has to master since it implies utilizing the instructional environment to a fully functioning state, which is fruitful to student learning. Another aspect that the findings indicated that teachers lack is communication. Findings reveal that from the perspective of student teachers, advisor teachers are inadequate at creating a communicative aura among educational shareholders, criticizing students negatively, showing a negative attitude toward students, poor utilization of language, failing to establish a healthy relationship with families and monotonous voice. Such inadequacies with regard to communication is another inhibitor from creating efficient and comprehensive learning environments. Regarding professional development, the findings display that teachers have problems with time management, not having enough knowledge in terms methods and techniques of instruction, not using enough material, disliking the profession of teaching, failure to consider students' readiness level in instruction and ignoring students with special needs. It is necessary that teachers exhibit a level of devotion to professional development to improve their practices and their approach to students with a mindset of lifelong learning. In reference to personality aspect, psychological violence against students, humiliating them, being a negative role model to them and not being focused are the most voiced lacking qualifications by student teachers. Such negative behaviors and attitudes by teachers are detrimental to students' well-being, and hence, inimical to their achievement. Students' achievement might increase if they are in the class with a teacher that they admire. Besides, negative personality traits of teachers might influence those of students, which is not a desired end in education. Finally, the findings also indicate that advisor teachers experience problems on creating a democratic learning environment and utilization of instructional material and technology.

Based on the findings of the study, we suggest that educational authorities organize in-service training sessions to work with teachers on such issues as effective class participation, effective use of class time, taking student traits into consideration in teaching, etc. Moreover, a more comprehensive system of teacher recruitment might be a possibility where teacher candidates go through a psychological examination to make an informed decision on who would be the most suitable for the teaching. Similarly, psychological support to advisor teachers in order to aid them to keep their well-being would be another option to eliminate lacking professional qualifications as they surfaced in this study. This study was limited to practicum students for one semester and included only a couple of departments in the Faculty of Education. Thus, we suggest that upcoming research on this topic to include a more comprehensive list of departments. Moreover, we recommend the upcoming scholarship on this topic to consider a survey study where the lacking professional qualifications would be studied with advisor teachers rather than student teachers to include the voices of the latter to the discussion as well. Besides, a longitudinal study would be fruitful to see if student teachers themselves encounter these problems when they become practicing teachers themselves.

\section{REFERENCES}

Abazaoğlu, İ., Yıldırım, O. ve Yıldızhan,Y. (2016). Geçmişten günümüze Türk eğitim sisteminde öğretmen yetiştirme. International Journal of Turkish Education Sciences, 4(6), 143-160.

Akiba, M., LeTendre, G. K., and Scribner, J. P. (2007). Teacher quality, opportunity gap, and national achievement in 46 countries. Educational Researcher, 36(7), 369-387.

Buldu, M. ( 2014). Öğretmen yeterlik düzeyi değerlendirmesi ve mesleki gelişim eğitimleri planlanması üzerine bir öneri. Millı̂ Ĕ̆itim, 204(1), 114-134.

Çelebi, N., Babaoğlan, E., Selçuk, G. and Peker, S. (2018). Performans değerlendirme formuna ilişkin öğretmen görüssleri. Ondokuz Mayıs Üniversitesi Ĕ̆itim Fakültesi Dergisi, 37(2), 211-233. 
Çelikten, M. Sanal, M., and Yeni, Y. (2005). Öğretmenlik mesleği ve özellikleri. Erciyes Üniversitesi Sosyal Bilimler Enstitüsü Dergisi, 19(2), 207-237.

Darling-Hammond, L. (2000). Teacher quality and student achievement: A review of state policy evidence. Education Policy Analysis Archives, 8(1), 1-44.

MEB (2017). Öğretmen mesleği genel yeterlilikleri: Ankara: Öğretmen Yetiştirme Genel Müdürlüğü.

MEB (2018). Uygulama öğrencilerinin Milli Eğgitim Bakanlığı'na bağh eğitim öğretim kurumlarında yapacakları öğretmenlik uygulamasına ilişkin yönerge. Tebliğler Dergisi, 81(2729), 1999-2012.

Özer, B., and Gelen, İ. (2008). Öğretmenlik mesleği genel yeterliklerine sahip olma düzeyler hakkında öğretmen adayları ve öğretmenlerin görüşlerinin değerlendirilmesi. Mustafa Kemal Üniversitesi Sosyal Bilimler Enstitüsü Dergisi, 5(9), 39-55.

Pehlivan, İ., Demirbaş, A., and Eroğlu, E. (2001). Öğretmenlerin performans değerlendirme modeli ve sicil raporları. Ankara: Millı̂ Eğitim Bakanlığ1

Sabuncuoğlu, O. (2016). Öğretmen gözlemlemenin öğretmeyi öğrenmedeki yeri nedir: Öğretmenin kariyerinde fark yaratabilir mi? Atatürk Üniversitesi Sosyal Bilimler Enstitüsü Dergisi, 20(1), 185-198.

Selçuk, Z., Palancı, M., Kandemir, M., and Dündar, H. (2014). Eğitim ve Bilim dergisinde yayınlanan araştırmaların eğilimleri: İçerik analizi. Ĕ̆itim ve Bilim, 39(173), 430-453.

Trumbull, D. J., and K., Fluet. (2008). What can be learned from writing about early field experiences? Teaching and Teacher Education, 24(6), 1672-1685. 